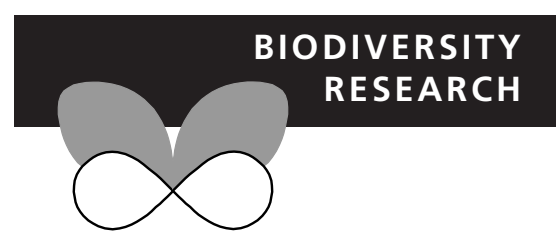

\title{
Dispersal of forest birds and trees along the Uruguay River in southern South America
}

\author{
Manuel Nores ${ }^{1, \star}$, María M. Cerana ${ }^{2}$ and Diego A. Serra ${ }^{3}$
}

${ }^{1}$ Centro de Zoología Aplicada/Conicet. C.C. 122, 5000 Córdoba, Argentina; ${ }^{2}$ Facultad de Ciencias Agropecuarias. C.C. 509, 5000 Córdoba, Argentina; ${ }^{3}$ Centro de Zoología Aplicada. C.C. 122, 5000 Córdoba, Argentina
${ }^{\star}$ Correspondence: Manuel Nores, Centro de Zoología Aplicada/Conicet. C.C. 122, 5000 Córdoba, Argentina. Tel.: 54-351-4332055; Fax.: 54-351-4332054;

E-mail:mnores@com.uncor.edu

\begin{abstract}
The Uruguay River starts in Serra do Mar in Brazil, runs through the Paranense forest, and flows southward through grassland and savannas. It has a continuous gallery forest of $750 \mathrm{~km}$ from the southern border of the Paranense forest to the river mouth. The gallery forest extends for $100 \mathrm{~km}$ more along the Río de la Plata. 125 $(68.7 \%)$ of the 182 species of forest birds recorded in the southern Paranense forest penetrate into the gallery forest of the Uruguay River and only 13 (7.1\%) reach the end of the gallery forest (Punta Lara). The number of bird species is inversely correlated $\left(r^{2}=0.942\right)$ with distance and the slope of the regression is 58.10. This means a decline in diversity with $32 \%$ of species lost per unit distance. A hundred and eighty forest tree species were recorded in the southern Paranense forest, of which $113(62.8 \%)$ penetrate into the gallery forest of the Uruguay River, and 28 (15.6\%) reach Punta Lara. The number of tree species is inversely correlated $\left(r^{2}=0.976\right)$ with distance and the slope of the regression is -45.62 . This means a decline in diversity with $25 \%$ of species lost per unit distance. The Uruguay River enables the dispersal of many species of forest birds and trees from the rain forest, but species richness tends to decrease with increased distance from the source area. A clear association pattern was found for birds between size, diet, habitat use and distance reached into the gallery forest. Species of smaller body size, granivores, insectivores and those that use both the interior and exterior parts of the gallery forest advanced noticeably further along the river than larger species, carnivores, nectarivores or frugivores, and those that frequent only a part of the forest. Similarly, a clear association between dispersal mechanism, water dependence and distance reached into the gallery forest was found for trees. Species with vegetative reproduction, zoochorous species and riparian species advanced markedly longer distances along the river than, anemochorous species and non-riparian species.
\end{abstract}

\section{Key words}

Birds, trees, distribution, gallery forest, Paranense Region, species/distance, South America.

\section{INTRODUCTION}

Rivers, with their associated vegetation, are crucial sources of food, refuge, and other resources for animals (Carothers et al., 1974). Within rain forest, riparian forest is barely evident, but in open areas it forms conspicuous galleries (Hueck, 1972). Although gallery forests are finger-like extensions of rain forest, ecologically they are somewhat different. They occur in regions where natural conditions are not favourable for forest and allow vast extensions in the range of forest dwelling species.

Despite the numerous studies of riparian wildlife (Bell, 1974; Hupp, 1982, 1983; Knopf, 1985; Nilsson, 1986, 1992; Tabacchi et al.,
1990; Gregory et al., 1991; Kalliola et al., 1992; Naiman et al., 1993; Mares \& Ernest, 1995; Stromberg et al., 1996; Nilsson et al., 1997, 1999; Kellman et al., 1998; Johnson et al., 1999), few authors have examined patterns of species richness along the entire course of a river (Short \& Horne, 1981; Nilsson, 1986; Nilsson et al., 1989; Silva, 1996).

Around the Tropic of Capricorn, in eastern South America, two major vegetation types cover virtually all the area: the rain forest (Paranense-Atlantic forest), extending through eastern and south-eastern Brazil, eastern Paraguay, and north-eastern Argentina, and non-forest vegetation (grassland and savannas) in central and southern Brazil, south-eastern Paraguay, eastern 


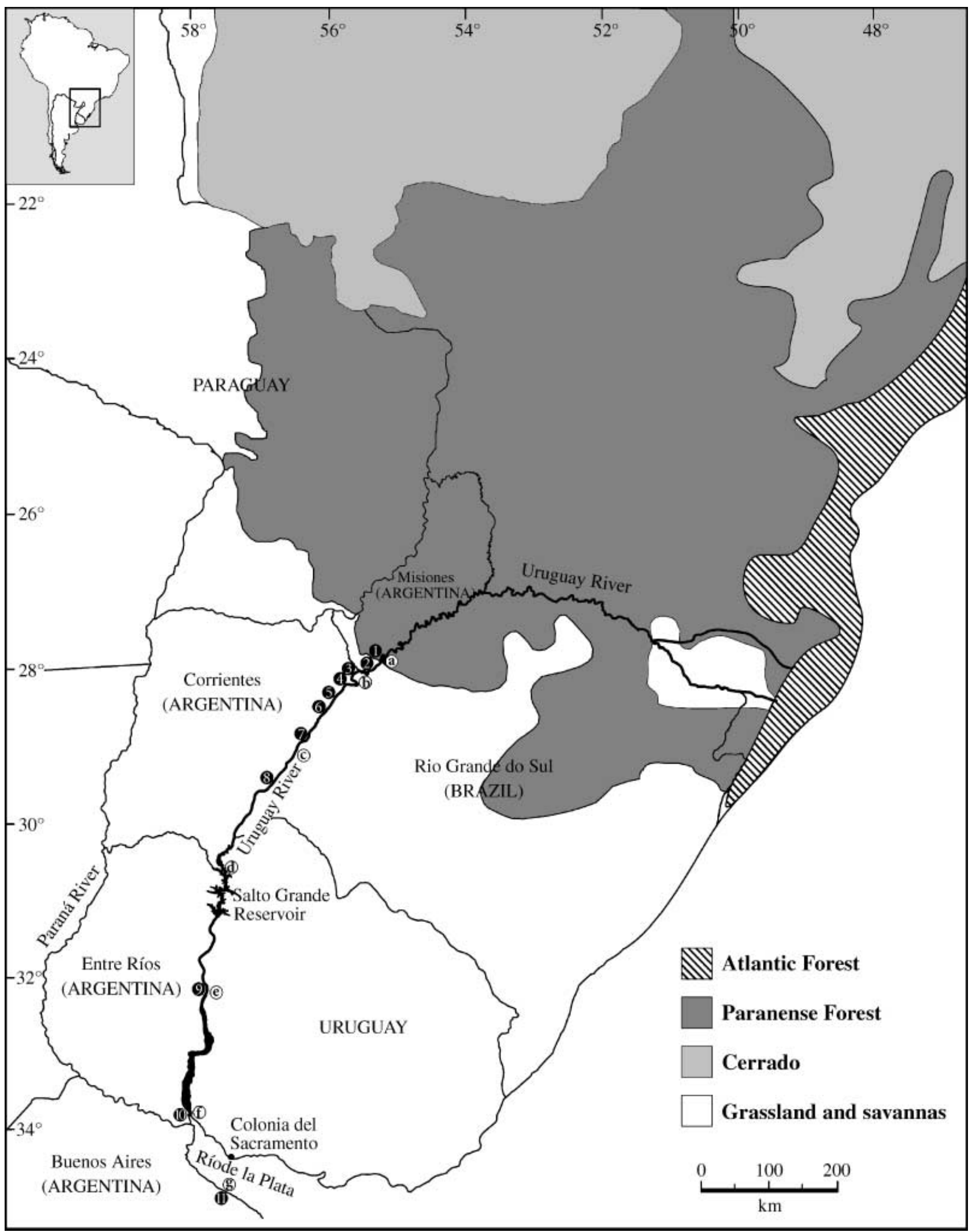

Figure 1 Map of the study area showing the location of forest and non-forest vegetation and location of the distribution points. Numbers indicate bird points: (1) Paranense forest border (2) Colonia Santa María (3) Garruchos (4) Colonia Garabí (5) Santo Tomé (6) Torrent (7) Alvear (8) Yapeyú (9) Colón (10) lower Paraná Delta, and (11) Punta Lara. Letters indicate tree points: (a) Paranense forest border (b) northern Corrientes (c) southern Corrientes (d) northern Entre Ríos (e) southern Entre Ríos (f) lower Paraná Delta, and (g) Punta Lara. 
Argentina, and Uruguay (Fig. 1). In predominantly non-forest regions (Cerrado, Chaco and Pampas), narrow and well-defined gallery forests occur along rivers and streams (Hueck, 1972). Gallery forests enable many forest species to disperse from the rain forest (Darrieu, 1986; Redford \& da Fonseca, 1986; Nores, 1992; Mares \& Ernest, 1995; Darrieu \& Camperi, 1996; Silva, 1996). However, species richness tends to decrease with increased distance from source areas (Silva \& Oniki, 1988; Nores, 1992; Silva, 1996).

To the south of the Tropic of Capricorn, gallery forests generally occur where annual precipitation is at least $900 \mathrm{~mm}$ and they have a close relation to the microclimate of rivers. According to Martínez Crovetto (1963), morning fogs protect the vegetation from winter frost and allow tropical and subtropical species to survive in temperate regions.

A major river of subtropical South America is the Uruguay River, with a total course of $1600 \mathrm{~km}$ starting in the southern part of the Atlantic forest, running through the Paranense forest and flowing southward through grassland and savannas (Fig. 1). It is $1.3 \mathrm{~km}$ wide at the beginning of the gallery forest and $13 \mathrm{~km}$ wide near its mouth. It joins the Paraná River and together they form the Río de la Plata. The Uruguay River has a conspicuous gallery forest of $750 \mathrm{~km}$ that extends for $100 \mathrm{~km}$ more along the first part of the Río de la Plata. The Paraná River, however, does not have a continuous gallery forest in this area. The gallery forest follows a decreasing temperature and rainfall gradient ranging from $20^{\circ} \mathrm{C}$ and $1600 \mathrm{~mm}$ (annual average) at its beginning in southern Misiones and north-western Rio Grande do Sul to $16^{\circ} \mathrm{C}$ and $900 \mathrm{~mm}$ at the end of the gallery forest in the Río de la Plata. During the rainy season the Uruguay River raises several meters and floods gallery forest along most of its course.

In this paper we describe the distance that Paranense birds and trees have advanced along the gallery forest of the Uruguay River (and its extension along the first part of the Río de la Plata) and evaluate the relationship between these distances and some ecological characteristics of the species. We also compare our bird data with Atlantic-Paranense bird data from gallery forests in the Cerrado region (Silva, 1996).

\section{METHODS}

The study was conducted from February 1999 to June 2001. These data were supplemented by data we had obtained previously at various sites of the Paranense-Atlantic forest of Brazil, Paraguay and Argentina, and along gallery forests of several rivers and streams originating in these forests. We covered most of the roads that give access to the Uruguay River (and to the first part of the Río de la Plata) to verify the presence or absence of gallery forest and determined the extent and continuity of the gallery forest using satellite images.

We selected all those species of forest birds and trees recorded in the gallery forest of the Uruguay River (and the first part of the Río de la Plata) and assumed that these species have expanded their range from the Paranense-Atlantic forest by following the gallery forest of these rivers. We evaluated the distance that forest birds and trees have advanced along the Uruguay River (and the Río de la Plata) by considering the distance for each species from the source area to its southernmost record. For this reason, we generated the figures treating the species as all continuously distributed.

Forest bird distribution along the Uruguay River (and the Río de la Plata) was determined from three sources: (i) the huge collection made by William Partridge in the 1960s, which was communicated mainly by Darrieu and colleagues (Darrieu \& Martínez, 1984; Darrieu, 1986, 1987, 1990; Darrieu \& Camperi, 1988, 1991, 1992, 1993a, 1993b, 1994, 1996, 1998); (ii) literature from Brazil (mainly from the works of Belton, 1984, 1985, 1994), Argentina, and Uruguay; and (iii) surveys conducted at various sites where Partridge did not collect, especially Santa María, Yapeyú, Colón and Punta Lara. Some occasional records, particularly from Buenos Aires Province (Narosky \& Di Giacomo, 1993), were evidently from escapees or vagrants. Most of these species are cage birds, recorded in unsuitable habitats, geographically far from their normal range. They were therefore excluded from further analysis. We surveyed bird species by visual and audio identification, and occasional mist netting.

To represent forest bird distribution along the river, 11 points were established that correspond to Partridge's collection sites and our ornithological surveys. Point 1 was on the southern border of the Paranense forest in southern Misiones and northeastern Rio Grande do Sul. Points 2-10 were located along the gallery forest of the Uruguay River, and point 11 at the end of the gallery forest on the Río de la Plata (Fig. 1).

Forest tree distribution along the Uruguay River (and the Río de la Plata) was determined from botanical literature from Brazil, Argentina and Uruguay, mainly the work of Dimitri et al. (1998). Additional sources used were taxonomic and geographical reviews, such as Hauman (1925); Cabrera \& Dawson (1944); MartínezCrovetto (1963); Reitz (1965-89); Burkart (1969-79); Dimitri (1974); Jozami \& Muñoz (1983); Troncoso \& Bacigalupo (1987); Hunziker (1994-2000); Daviña et al. (1999).

To represent forest tree distribution along the rivers we established seven points, in locations similar to those of the bird points as above (Fig. 1).

To analyse the relationship between the distance reached by Paranense birds into the gallery forest and some of their ecological characteristics, we classified each taxon in categories of size, diet, habitat use and migratory status. Size categories are the following: very small up to $12 \mathrm{~cm}$, small $13-20$, medium 21-30 and large more than $30 \mathrm{~cm}$. Diet categories include insectivores (species whose diet includes mostly insects and other arthropods), frugivores (species whose diet is mainly based on fruits, and rarely on insects), carnivores (species that feed mainly on terrestrial vertebrates or fishes), granivores (species whose diet is based primarily on grains and seeds, generally including some insects and other arthropods), nectarivores (species that feed mainly on nectar, generally including some arthropods), and omnivores (species whose diet includes fruits/seeds and insects/small vertebrates in similar proportions). Habitat use: interior (species that concentrate their activities mainly in the understorey and subcanopy of the gallery forest), exterior (species that concentrate their activities mainly in the canopy and/or borders) and both (species that use both interior and exterior of the gallery forest) (Silva, 1996). Migratory status: migratory species and residents. 


\begin{tabular}{|c|c|c|c|c|c|c|c|c|c|c|c|c|c|c|c|}
\hline Species & $\stackrel{\vec{\nu}}{\vec{a}}$ & $\stackrel{\tilde{N}}{\tilde{N}}$ & 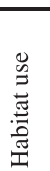 & 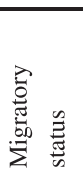 & 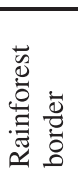 & 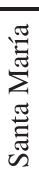 & $\begin{array}{l}\stackrel{2}{0} \\
\frac{0}{0} \\
\stackrel{0}{0} \\
0 \\
0\end{array}$ & 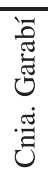 & 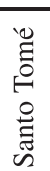 & $\underset{0}{\overrightarrow{0}}$ & 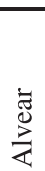 & 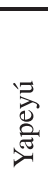 & $\frac{\sqrt{0}}{8}$ & 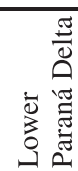 & 㞼 \\
\hline Crypturellus obsoletus & $\mathrm{O}$ & $\mathrm{M}$ & I & $\mathrm{R}$ & 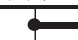 & & & & & & & & & & \\
\hline Crypturellus parvirostris & $\mathrm{O}$ & S & I & $\mathrm{R}$ & & & & & & & & & & & \\
\hline Tigrisoma fasciatum & $\mathrm{C}$ & $\mathrm{L}$ & $\mathrm{E}$ & $\mathrm{R}$ & . & & & & & & & & & & \\
\hline Mesembrinibis cayennensis & I & $\mathrm{L}$ & $\mathrm{E}$ & $\mathrm{R}$ & $\bullet$ & & & & & & & & & & \\
\hline Mergus octosetaceus & $\mathrm{C}$ & $\mathrm{L}$ & $\mathrm{E}$ & $\mathrm{R}$ & . & & & & & & & & & & \\
\hline Leptodon cayanensis & $\mathrm{C}$ & $\mathrm{L}$ & $\mathrm{E}$ & $\mathrm{R}$ & & & & & & & & & & & \\
\hline Chondrohierax uncinatus & $\mathrm{C}$ & $\mathrm{L}$ & $\mathrm{E}$ & $\mathrm{R}$ & - & & & & & & & & & & \\
\hline Harpagus diodon & $\mathrm{C}$ & M & B & $\mathrm{R}$ & . & & & & & & & & & & \\
\hline Accipiter bicolor & $\mathrm{C}$ & $\mathrm{L}$ & $\mathrm{E}$ & $\mathrm{R}$ & 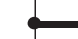 & & & & & & & & & & \\
\hline Accipiter poliogaster & $\mathrm{C}$ & $\mathrm{L}$ & E & M & 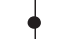 & & & & & & & & & & \\
\hline Morphnus guianensis & $\mathrm{C}$ & $\mathrm{L}$ & E & $\mathrm{R}$ & 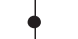 & & & & & & & & & & \\
\hline Spizaetus ornatus & $\mathrm{C}$ & $\mathrm{L}$ & B & $\mathrm{R}$ & 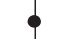 & & & & & & & & & & \\
\hline Spizaetus tyrannus & $\mathrm{C}$ & $\mathrm{L}$ & B & $\mathrm{R}$ & - & & & & & & & & & & \\
\hline Micrastur ruficollis & $\mathrm{C}$ & $\mathrm{L}$ & B & $\mathrm{R}$ & - & & & & & & & & & & \\
\hline Micrastur semitorquatus & $\mathrm{C}$ & $\mathrm{L}$ & B & $\mathrm{R}$ & . & & & & & & & & & & \\
\hline Penelope superciliaris & $\mathrm{F}$ & $\mathrm{L}$ & B & $\mathrm{R}$ & - & & & & & & & & & & \\
\hline Penelope obscura & $\mathrm{F}$ & $\mathrm{L}$ & B & $\mathrm{R}$ & 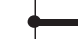 & & & & & & & & & & \\
\hline Aburria jacutinga & $\mathrm{F}$ & $\mathrm{L}$ & I & $\mathrm{R}$ & 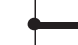 & & & & & & & & & & \\
\hline Odontophorus capueira & $\mathrm{F}$ & M & I & $\mathrm{R}$ & - & & & & & & & & & & \\
\hline Aramides saracura & $\mathrm{O}$ & $\mathrm{L}$ & B & $\mathrm{R}$ & 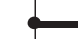 & & & & & & & & & & \\
\hline Ortygonax nigricans & $\mathrm{F}$ & M & B & $\mathrm{R}$ & & & & & & & & & & & \\
\hline Columba cayennensis & $\mathrm{F}$ & M & $\mathrm{E}$ & M & & & & & & & & & & & \\
\hline Leptotila rufaxilla & $\mathrm{F}$ & $\mathrm{M}$ & I & $\mathrm{R}$ & & & & & & & & & & & \\
\hline Geotrygon violacea & $\mathrm{F}$ & M & I & $\mathrm{R}$ & & & & & & & & & & & \\
\hline Ara chloroptera & $\mathrm{F}$ & $\mathrm{L}$ & $\mathrm{E}$ & $\mathrm{R}$ & 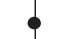 & & & & & & & & & & \\
\hline Ara maracana & $\mathrm{F}$ & $\mathrm{L}$ & $\mathrm{E}$ & $\mathrm{R}$ & 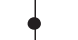 & & & & & & & & & & \\
\hline Aratinga leucophthalma & $\mathrm{F}$ & $\mathrm{L}$ & $\mathrm{E}$ & $\mathrm{R}$ & & & & & & & & & & & \\
\hline Pyrrhura frontalis & $\mathrm{F}$ & $S$ & $\mathrm{E}$ & $\mathrm{R}$ & & & & & & & & & & & \\
\hline Forpus crassirostris & $\mathrm{F}$ & $\mathrm{V}$ & $\mathrm{E}$ & $\mathrm{R}$ & - & & & & & & & & & & \\
\hline Pionopsitta pileata & $\mathrm{F}$ & S & $\mathrm{E}$ & $\mathrm{R}$ & 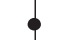 & & & & & & & & & & \\
\hline Pionus maximiliani & $\mathrm{F}$ & M & $\mathrm{E}$ & $\mathrm{R}$ & & & & & & & & & & & \\
\hline Amazona pretrei & $\mathrm{F}$ & M & $\mathrm{E}$ & $\mathrm{R}$ & • & & & & & & & & & & \\
\hline Amazona vinacea & $\mathrm{F}$ & M & $\mathrm{E}$ & $\mathrm{R}$ & 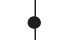 & & & & & & & & & & \\
\hline Piaya cayana & I & $\mathrm{L}$ & B & $\mathrm{R}$ & & & & & & & & & & & \\
\hline Dromococcyx pavoninus & I & $\mathrm{M}$ & I & $\mathrm{R}$ & & & & & & & & & & & \\
\hline Dromococcyx phasianellus & I & $\mathrm{L}$ & B & $\mathrm{R}$ & 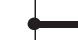 & & & & & & & & & & \\
\hline Otus atricapillus & I & M & B & $\mathrm{R}$ & 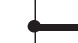 & & & & & & & & & & \\
\hline Pulsatrix koeniswaldiana & $\mathrm{C}$ & $\mathrm{L}$ & B & $\mathrm{R}$ & . & & & & & & & & & & \\
\hline Aegolius harrisii & $\mathrm{C}$ & S & I & $\mathrm{R}$ & . & & & & & & & & & & \\
\hline Lurocalis semitorquatus & I & S & B & M & I & & & & & & & & & & \\
\hline Nyctidromus albicollis & I & M & $\mathrm{E}$ & $\mathrm{R}$ & & & & & & & & & & & \\
\hline Caprimulgus sericocaudatus & I & $\mathrm{M}$ & I & $\mathrm{R}$ & & & & & & & & & & & \\
\hline Aerornis senex & I & $\mathrm{S}$ & $\mathrm{E}$ & $\mathrm{R}$ & 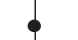 & & & & & & & & & & \\
\hline Chaetura cinereiventris & I & $\mathrm{V}$ & $\mathrm{E}$ & $\mathrm{R}$ & & & & & & & & & & & \\
\hline Phaethornis eurynome & $\mathrm{N}$ & $\mathrm{V}$ & I & $\mathrm{R}$ & . & & & & & & & & & & \\
\hline Anthracothorax nigricollis & $\mathrm{N}$ & V & $\mathrm{E}$ & $\mathrm{R}$ & & & & & & & & & & & \\
\hline Stephanoxis lalandi & $\mathrm{N}$ & $\mathrm{V}$ & B & $\mathrm{R}$ & & & & & & & & & & & \\
\hline Thalurania furcata & $\mathrm{N}$ & V & B & $\mathrm{R}$ & - & & & & & & & & & & \\
\hline Thalurania glaucopis & $\mathrm{N}$ & V & B & $\mathrm{R}$ & - & & & & & & & & & & \\
\hline Amazilia versicolor & $\mathrm{N}$ & V & B & $\mathrm{R}$ & & & & & & & & & & & \\
\hline Calliphlox amethystina & $\mathrm{N}$ & V & $\mathrm{E}$ & M & . & & & & & & & & & & \\
\hline Trogon rufus & $\mathrm{O}$ & M & B & $\mathrm{R}$ & & & & & & & & & & & \\
\hline Trogon surrucura & $\mathrm{O}$ & M & B & $\mathrm{R}$ & & & & & & & & & & & \\
\hline Baryphthengus ruficapillus & $\mathrm{O}$ & $\mathrm{L}$ & I & $\mathrm{R}$ & I & & & & & & & & & & \\
\hline Nystalus chacuru & I & $S$ & $\mathrm{E}$ & $\mathrm{R}$ & & & & & & & & & & & \\
\hline Nonnula rubecula & I & $\mathrm{S}$ & B & $\mathrm{R}$ & & & & & & & & & & & \\
\hline Pteroglossus castanotis & $\mathrm{O}$ & $\mathrm{L}$ & $\mathrm{E}$ & $\mathrm{R}$ & 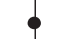 & & & & & & & & & & \\
\hline Ramphastos dicolorus & $\mathrm{O}$ & $\mathrm{L}$ & $\mathrm{E}$ & $\mathrm{R}$ & & & & & & & & & & & \\
\hline Ramphastos toco & $\mathrm{O}$ & $\mathrm{L}$ & $\mathrm{E}$ & $\mathrm{R}$ & & & & & & & & & & & \\
\hline Picumnus nebulosus & I & $\mathrm{V}$ & B & $\mathrm{R}$ & & & & & & & & & & & \\
\hline Picumnus cirratus & I & $\mathrm{V}$ & I & $\mathrm{R}$ & & & & & & & & & & & \\
\hline Melanerpes flavifrons & $\mathrm{O}$ & $S$ & $\mathrm{E}$ & $\mathrm{R}$ & 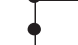 & & & & & & & & & & \\
\hline Piculus aurulentus & $\mathrm{O}$ & M & B & $\mathrm{R}$ & & & & & & & & & & & \\
\hline
\end{tabular}

Figure 2 Ecological characteristics and distribution of forest birds along the gallery forest of the Uruguay River and in the first part of the Río de la Plata. The black lines indicate the distance that each species advances from the source area to its southernmost record. 


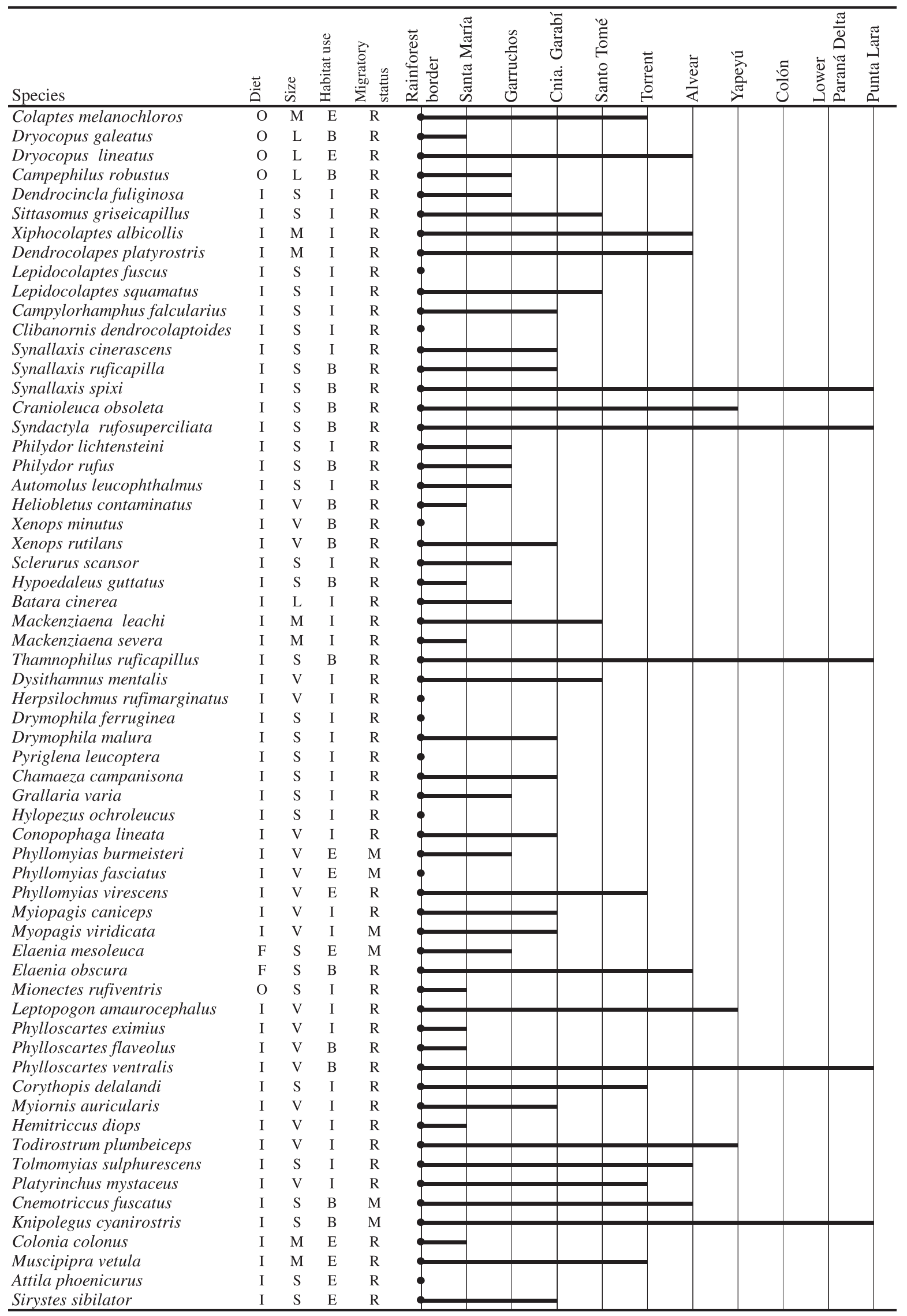

Figure 2 Continued 


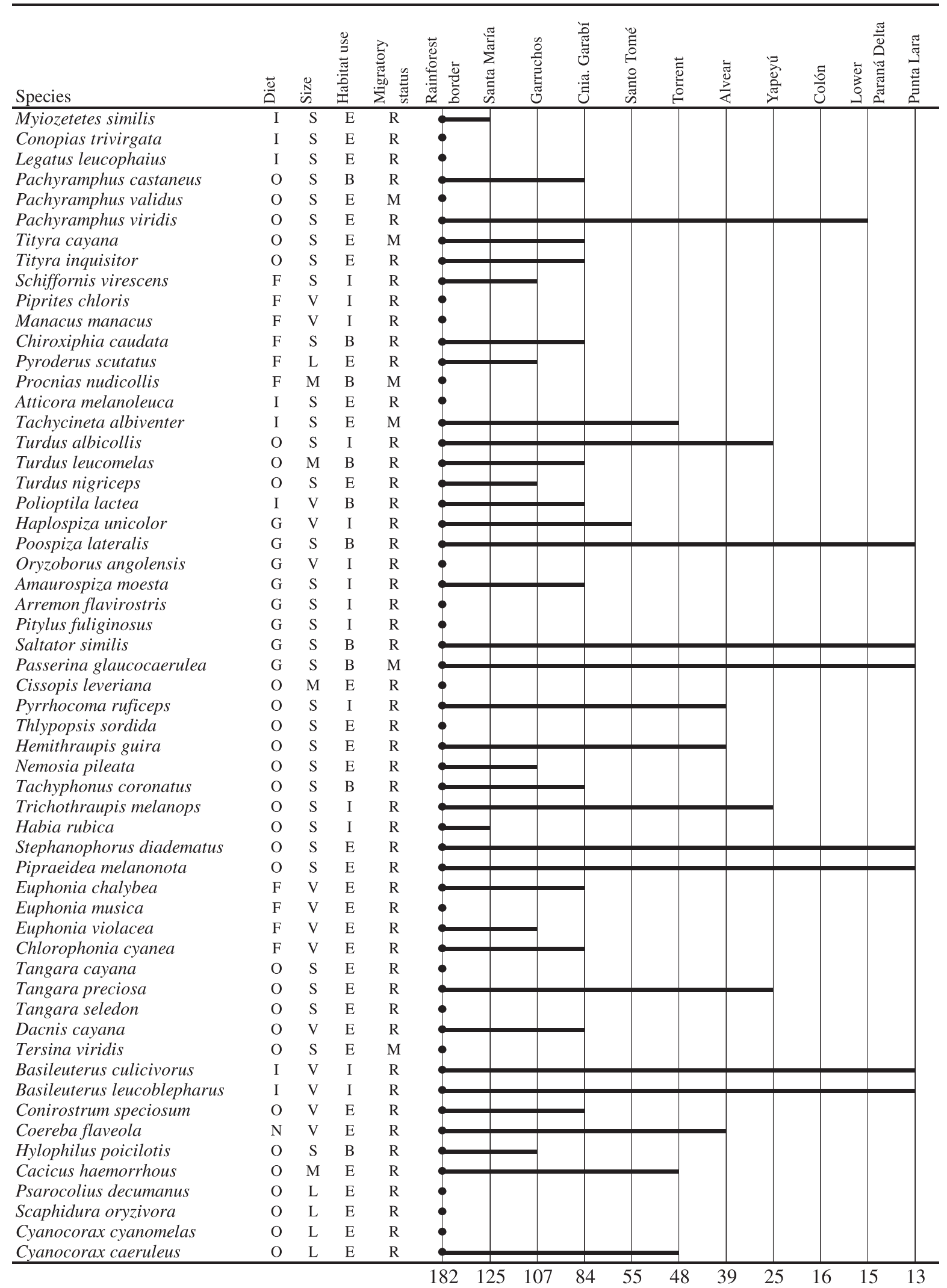

Figure 2 Continued 
Table 1 Distribution of forest birds by categories of diet, size, habitat use migratory status and distance reached into the gallery forest of the Uruguay River and the Rió de la Plata I: insectivores, F: frugivores, C: carnivores, G: granivores, N: nectarivores, O: omnivores. VM: very small, S: small, M: medium, L: large. I: interior, E: exterior, B: both. M: migratory, R: resident

\begin{tabular}{|c|c|c|c|c|c|c|c|c|c|c|c|c|c|c|c|c|}
\hline & \multirow[b]{2}{*}{ Total } & \multicolumn{6}{|l|}{ Diet } & \multicolumn{4}{|l|}{ Size } & \multicolumn{2}{|c|}{ Habitat } & \multicolumn{3}{|c|}{ Migratory Status } \\
\hline & & I & $\mathrm{F}$ & $\mathrm{C}$ & G & $\mathrm{N}$ & $\mathrm{O}$ & VS & S & M & $\mathrm{L}$ & I & $\mathrm{E}$ & $\mathrm{B}$ & M & $\mathrm{R}$ \\
\hline Rainforest border & 182 & 77 & 29 & 14 & 8 & 8 & 46 & 45 & 72 & 31 & 34 & 61 & 71 & 50 & 17 & 165 \\
\hline Santa María & 125 & 63 & 17 & 3 & 5 & 4 & 33 & 33 & 52 & 25 & 15 & 46 & 39 & 40 & 11 & 114 \\
\hline Garruchos & 107 & 52 & 14 & 3 & 5 & 4 & 29 & 29 & 46 & 18 & 14 & 38 & 35 & 34 & 11 & 96 \\
\hline Cnia. Garabí & 84 & 40 & 10 & 2 & 5 & 3 & 24 & 23 & 36 & 16 & 9 & 30 & 26 & 28 & 7 & 77 \\
\hline Santo Tomé & 55 & 27 & 4 & 0 & 4 & 3 & 17 & 13 & 24 & 12 & 6 & 19 & 16 & 20 & 4 & 51 \\
\hline Torrent & 48 & 23 & 4 & 0 & 3 & 2 & 16 & 10 & 21 & 11 & 6 & 13 & 16 & 19 & 4 & 44 \\
\hline Alvear & 39 & 18 & 4 & 0 & 3 & 1 & 13 & 7 & 19 & 8 & 5 & 11 & 10 & 18 & 3 & 36 \\
\hline Yapeyú & 25 & 12 & 2 & 0 & 3 & 0 & 8 & 5 & 14 & 3 & 3 & 7 & 4 & 14 & 2 & 23 \\
\hline Colón & 16 & 8 & 2 & 0 & 3 & 0 & 3 & 3 & 10 & 1 & 2 & 3 & 3 & 10 & 2 & 14 \\
\hline Lower Paraná Delta & 15 & 8 & 1 & 0 & 3 & 0 & 3 & 3 & 10 & 0 & 2 & 2 & 3 & 10 & 2 & 13 \\
\hline Punta Lara & 13 & 8 & 0 & 0 & 3 & 0 & 2 & 3 & 9 & 0 & 1 & 2 & 2 & 9 & 2 & 11 \\
\hline$\%$ & 7.1 & 10.39 & 0 & 0 & 37 & 0 & 4.35 & 6.66 & 12.5 & 0 & 2.94 & 3.28 & 2.81 & 18 & 11.76 & 6.66 \\
\hline
\end{tabular}

For trees we classified each taxon in categories of water dependence (riparian and non-riparian species) and dispersal mechanism: V: vegetative reproduction, $\mathrm{Z}$ : zoochorous species, A: anemochorous species, $\mathrm{H}$ : hydrochorous species.

The order of the families and the generic and specific names of bird species follow Stotz et al. (1996). Tree families are arranged following the Angiosperm Phylogeny Group II (APG II, 2003), and genera and species are in alphabetical order. Nomenclature follows Zuloaga et al. (1994), and Zuloaga \& Morrone (1996-99).

We used a semilog regression to determine the relation between the number of species and distance of birds and trees along the river and a chi-square analysis to compare the number of riparian and non-riparian species of trees that go into the gallery forest or reach the end of the gallery forest.

\section{RESULTS}

Satellite images and survey data reveal that the Uruguay River formerly had a continuous gallery forest from southern Misiones and north-western Rio Grande do Sul to its mouth in the Río de la Plata, with a maximum width of $1000 \mathrm{~m}$ on each side of the river. We found only one apparently natural short interruption, where the gallery forest is replaced by xerophytic woodland. It is located in Monte Caseros (Corrientes) and is about $2 \mathrm{~km}$ long. From the mouth of the Uruguay River, the gallery forest extends for $100 \mathrm{~km}$ more along the Argentine coast of the Río de la Plata to Punta Lara (Cabrera \& Dawson, 1944) and for $60 \mathrm{~km}$ along the Uruguayan side to $7 \mathrm{~km}$ upstream of the city of Colonia de Sacramento (pers. obs.).

During the 20th century, human constructions and forest exploitation interrupted the gallery forest in several places or changed the floristic composition of the vegetation. The most important disturbance by far is the Salto Grande reservoir which flooded and destroyed $100 \mathrm{~km}$ of gallery forest (Fig. 1). In spite of the fact that more than 20 years have passed since Salto

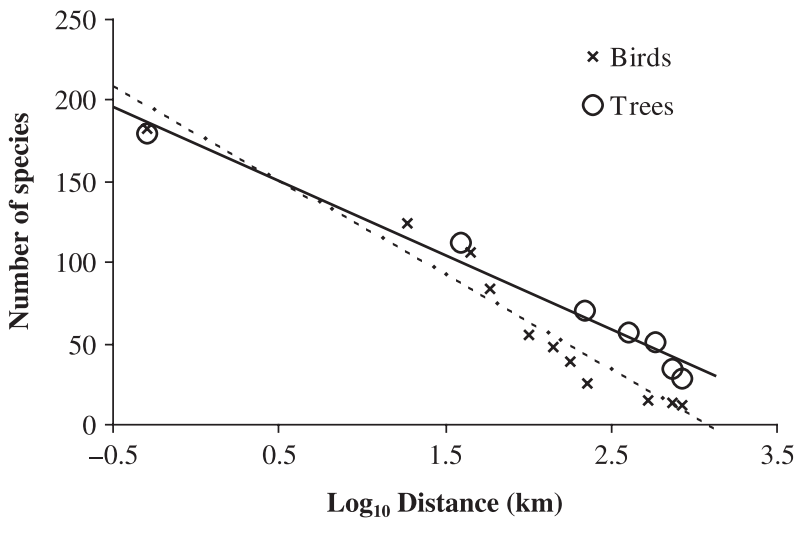

Figure 3 Species/distance curve for forest birds and trees on the Uruguay River and in the first part of the Río de la Plata.

Grande was constructed, there is no evidence that gallery forest is forming on its margins.

Hundred and twenty five (68.7\%) of the 182 species of forest birds recorded in the Paranense forest in southern Misiones and north-western Rio Grande do Sul (Belton, 1984, 1985, 1994; Chebez, 1996) go into the gallery forest of the Uruguay River and only $13(7.1 \%)$ reach Punta Lara (Fig. 2). The number of species is inversely correlated $\left(r^{2}=0.942\right)$ with distance and the slope of the regression is -58.10 ; SE 4.81(Fig. 3). This means a decline in diversity with $32 \%$ of species lost per unit distance.

A clear association pattern was found for birds between size, diet, habitat use and distance reached into the gallery forest. Species of smaller body size, granivores, insectivores and those that use both the interior and exterior parts of the gallery forest advanced markedly longer distances along the river than the other groups (Table 1). Eleven migratory species (Columba cayennensis, Lurocalis semitorquatus, Anthracothorax nigricollis, Phyllomyias burmeisteri, Myiopagis viridicata, Elaenia mesoleuca, Cnemotriccus fuscatus, Knipolegus cyanirostris, Tityra cayana, 
Table 2 Distribution of forest trees by categories of water dependence, dispersal mechanism and distance reached into the gallery forest of the Uruguay River and the Rió de la Plata

\begin{tabular}{|c|c|c|c|c|c|c|}
\hline & \multirow[b]{2}{*}{ Total } & \multicolumn{3}{|c|}{$\begin{array}{l}\text { Dispersal } \\
\text { mechanism }\end{array}$} & \multicolumn{2}{|c|}{$\begin{array}{l}\text { Water } \\
\text { dependence }\end{array}$} \\
\hline & & $\mathrm{V}$ & Z & A & $\mathrm{R}$ & NR \\
\hline Rainforest border & 180 & 4 & 142 & 34 & 43 & 137 \\
\hline Northern Corrientes & 112 & 2 & 85 & 26 & 30 & 83 \\
\hline Southern Corrientes & 69 & 2 & 56 & 12 & 25 & 45 \\
\hline Northern Entre Ríos & 56 & 2 & 47 & 8 & 21 & 36 \\
\hline Southern Entre Ríos & 50 & 1 & 43 & 7 & 19 & 32 \\
\hline Lower Paraná Delta & 35 & 1 & 29 & 5 & 15 & 20 \\
\hline Punta Lara & 28 & 1 & 24 & 3 & 13 & 15 \\
\hline$\%$ & 15.6 & 25 & 16.9 & 8.8 & 30.2 & 10.9 \\
\hline
\end{tabular}

V: vegetative reproduction, Z: zoochorous, A: anemochorous,

$\mathrm{H}$ : hydrochorous. R: riparian, NR: non-riparian

Tachycineta albiventer, and Passerina glaucocaerulea) were recorded in the gallery forest of the Uruguay River. With the exception of Knipolegus cyanirostris and Passerina glaucocaerulea that reach Punta Lara, all of them only penetrate a short distance (maximum $180 \mathrm{~km}$ ) along the Uruguay River.

In the Paranense forest in southern Misiones and northwestern Rio Grande do Sul 180 forest tree species were recorded, of which 43 are restricted to riparian habitats (Martínez Crovetto, 1963). From the total of species recorded 113 (62.8\%) go into the gallery forest of the Uruguay River and $28(15.6 \%)$ reach the end of the gallery forest (Fig. 4). The number of species is inversely correlated $\left(r^{2}=0.976\right)$ with distance and the slope of the regression is -45.62 ; SE 3.11 (Fig. 3). This means a decline in diversity with $25 \%$ of species lost per unit distance.

A clear association pattern was also found for trees between ecological characteristics and distance reached into the gallery forest (Table 2). Vegetative reproduction species, zoochorous species and riparian species advanced markedly greater distances along the river than anemochorous species and non-riparian species. The species that reproduce mainly vegetatively were those that advanced more distance along the Uruguay River. However, this has little influence on the system because only four species are in this category.

\section{DISCUSSION}

The distribution of forest birds and trees along the Uruguay River shows that the river enables many species to disperse from the rain forest. But, as expected in this type of study (Silva \& Oniki, 1988; Nores, 1992; Silva, 1996), the importance of the river decreases with increasing distance from the source area.

The passage from the Paranense forest to the gallery forest of the Uruguay River implies that species must not only pass the bottleneck of the change from the broad rain forest to the narrow gallery forest but must also meet all the biological requirements of a small and narrow area. This constitutes a 'filter' which $31.3 \%$ of birds and $37.2 \%$ of tree species do not pass through. Lastly, to advance down the Uruguay River implies that species must at least have a tolerance for cooler and drier environments.

Although distribution patterns along the Uruguay River are similar for birds and trees, trees have a higher percentage of species reaching the end of the gallery forest ( $15.6 \%$ vs. $7.1 \%)$ and a less steep species/distance slope ( -45.62 vs. -58.10$)$.

Riparian species of trees advanced markedly longer distances along the river than non-riparian species (Table 2). A question arising from this pattern is whether being a riparian species facilitates passage from the Paranense forest to the gallery forest, or makes advance along the river easier. The results suggest the second option. Although the percentage of species entering the gallery forest is somewhat higher among riparian species (69.7\%) than non-riparian species $(60.6 \%)$, the difference is not significant $\left(\chi^{2}=1.18 ; \mathrm{Df}=1 ; P=0.277\right)$, but the percentage of riparian species $(30.2 \%)$ that reach the end of the gallery forest is significantly higher $\left(\chi^{2}=9.26\right.$; $\left.\mathrm{Df}=1 ; P=0.0023\right)$ than that of non-riparian species $(10.9 \%)$. The presence of a relatively high number of riparian species of trees would explain why trees have a higher percentage of species reaching the end of the gallery forest and a less steep species/distance slope than birds. In the Paranense forest there are also some riparian species of birds but only one (Knipolegus cyanirostris) reaches the end of the gallery forest.

Silva (1996) studied distribution along gallery forests in the Cerrado region of forest birds from two sources: AtlanticParanense forest and Amazonia. To compare our results with those of Silva's Atlantic-Paranense forest, we grouped the bird data according to his distance categories $(0-250 \mathrm{~km}, 251-500 \mathrm{~km}$, $501-750 \mathrm{~km}$, and more than $750 \mathrm{~km}$ ). In the Uruguay River the first category $(0-250 \mathrm{~km})$ is approximately in the subtropical zone and the remaining categories are in the temperate zone.

One unexpected difference between the two systems is that the number of species of Atlantic-Paranense birds recorded in the gallery forests of the Cerrado rivers (78) is much lower than the number of species recorded in the Uruguay River (125), even though the source area species pool is larger in the former than in the latter. Another difference is in the bird distribution pattern. In the Cerrado only $50 \%$ of the species that go into the gallery forests maintain their ranges within $0-250 \mathrm{~km}$, while in the Uruguay River $87 \%$ of the species are restricted to this distance category. This is probably because gallery forests of the Cerrado region are in the tropical zone with a more uniform temperature, while in the Uruguay River the gallery forest occurs in the subtropical and temperate zone and follows a decreasing temperature gradient.

Of the 16 remaining species that go beyond $250 \mathrm{~km}$ in the Uruguay River, one extends to $500 \mathrm{~km}$, two extend to $750 \mathrm{~km}$, and 13 exceed $750 \mathrm{~km}$ and reach Punta Lara. This means that most of the species which pass the first $250 \mathrm{~km}$ reach the end of the gallery forest. These are species with higher adaptability and most of them can sometimes go some distance outside gallery forests and colonize isolated — natural or exotic — forest habitats (e.g. Synallaxis spixi, Syndactyla rufosuperciliata, Thamnophilus 


\begin{tabular}{|c|c|c|c|c|c|c|c|c|c|}
\hline Species & 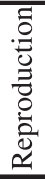 & 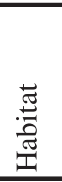 & 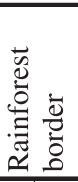 & 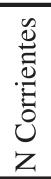 & 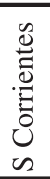 & 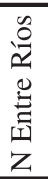 & 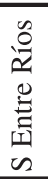 & 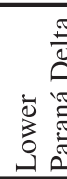 & 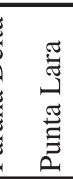 \\
\hline Nectandra angustifolia & $\bar{Z}$ & $\bar{R}$ & - & & & & & & \\
\hline Nectandra lanceolata & $\mathrm{Z}$ & NR & & & & & & & \\
\hline Nectandra megapotamica & Z & NR & & & & & & & \\
\hline Ocotea diospyrifolia & Z & NR & - & & & & & & \\
\hline Ocotea lancifolia & Z & $\mathrm{R}$ & - & & & & & & \\
\hline Ocotea puberula & Z & NR & & & & & & & \\
\hline Rollinia emarginata & Z & NR & & & & & & & \\
\hline Rollinia salicifolia & Z & NR & & & & & & & \\
\hline Acrocomia totai & $\mathrm{Z}$ & NR & & & & & & & \\
\hline Allagoptera campestris & $\mathrm{Z}$ & NR & - & & & & & & \\
\hline Syagrus romanzoffiana & $\mathrm{Z}$ & NR & & & & & & & \\
\hline Guadua angustifolia & V & $\mathrm{R}$ & & & & & & & \\
\hline Guadua chacoensis & $\mathrm{V}$ & NR & • & & & & & & \\
\hline Guadua trinii & $\mathrm{V}$ & NR & & & & & & & \\
\hline Merostachys clausseni & $\mathrm{V}$ & NR & ? & & & & & & \\
\hline Achatocarpus praecox & $\mathrm{Z}$ & NR & . & & & & & & \\
\hline Phytolacca dioica & $\mathrm{Z}$ & NR & & & & & & & \\
\hline Pisonia aculeata & $\mathrm{Z}$ & NR & & & & & & & \\
\hline Coccoloba cordata & $\mathrm{Z}$ & NR & 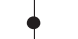 & & & & & & \\
\hline Ruprechtia brachysepala & A & NR & & & & & & & \\
\hline Ruprechtia laxiflora & A & NR & & & & & & & \\
\hline Ruprechtia salicifolia & A & $\mathrm{R}$ & & & & & & & \\
\hline Acanthosyris spinescens & $\mathrm{Z}$ & $\mathrm{R}$ & 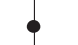 & & & & & & \\
\hline Terminalia australis & A & $\mathrm{R}$ & & & & & & & \\
\hline Terminalia triflora & A & $\mathrm{R}$ & 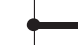 & & & & & & \\
\hline Miconia pusilliflora & $\mathrm{Z}$ & NR & - & & & & & & \\
\hline Blepharocalyx salicifolius & $\mathrm{Z}$ & $\mathrm{R}$ & - & & & & & & \\
\hline Calycorectes psidiiflorus & $\mathrm{Z}$ & NR & - & & & & & & \\
\hline Calyptranthes concinna & $\mathrm{Z}$ & NR & - & & & & & & \\
\hline Campomanesia guazumifolia & $\mathrm{Z}$ & NR & & & & & & & \\
\hline Campomanesia xanthocarpa & $\mathrm{Z}$ & NR & & & & & & & \\
\hline Eugenia burkartiana & $\mathrm{Z}$ & $\mathrm{R}$ & 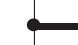 & & & & & & \\
\hline Eugenia hyemalis & $\mathrm{Z}$ & NR & - & & & & & & \\
\hline Eugenia involucrata & $\mathrm{Z}$ & NR & - & & & & & & \\
\hline Eugenia mansoni & $\bar{Z}$ & NR & 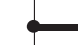 & & & & & & \\
\hline Eugenia pyriformis & $\mathrm{Z}$ & NR & 0 & & & & & & \\
\hline Eugenia repanda & $\mathrm{Z}$ & NR & - & & & & & & \\
\hline Eugenia uniflora & $\mathrm{Z}$ & NR & & & & & & & \\
\hline Eugenia uruguayensis & $\mathrm{Z}$ & NR & 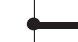 & & & & & & \\
\hline Guapurium peruvianum & $\mathrm{Z}$ & NR & - & & & & & & \\
\hline Hexachlamis edulis & $\mathrm{Z}$ & $\mathrm{R}$ & & & & & & & \\
\hline Myrceugenia euosma & $\mathrm{Z}$ & NR & $\bullet$ & & & & & & \\
\hline Myrceugenia glaucescens & Z & $\mathrm{R}$ & & & & & & & \\
\hline Myrcia bombycina & Z & NR & & & & & & & \\
\hline Myrcia laruotteana & $\mathrm{Z}$ & NR & & & & & & & \\
\hline Myrcia selloi & $\mathrm{Z}$ & $\mathrm{R}$ & & & & & & & \\
\hline Paramyrciaria delicatula & $\mathrm{Z}$ & NR & - & & & & & & \\
\hline Plinia rivularis & $\mathrm{Z}$ & NR & - & & & & & & \\
\hline Psidium guajava & Z & $\mathrm{R}$ & & & & & & & \\
\hline Psidium guineense & $\mathrm{Z}$ & NR & - & & & & & & \\
\hline Psidium kennedyanum & $\mathrm{Z}$ & NR & - & & & & & & \\
\hline Psidium nutans & $\mathrm{Z}$ & NR & - & & & & & & \\
\hline Maytenus ilicifolia & $\mathrm{Z}$ & NR & & & & & & & \\
\hline Schaefferia argentinensis & $\mathrm{Z}$ & $\mathrm{R}$ & - & & & & & & \\
\hline Acosmium subelegans & $\mathrm{Z}$ & NR & - & & & & & & \\
\hline Aeschynomene sensitiva & Z & NR & & & & & & & \\
\hline Albizia inundata & $\mathrm{Z}$ & NR & & & & & & & \\
\hline Anadenanthera colubrina & $\mathrm{Z}$ & NR & - & & & & & & \\
\hline Apuleia leiocarpa & A & NR & & & & & & & \\
\hline Bauhinia forficata & Z & NR & & & & & & & \\
\hline Bauhinia uruguayensis & $\mathrm{Z}$ & $\mathrm{NR}$ & & & & & & & \\
\hline Calliandra foliolosa & $\mathrm{Z}$ & NR & • & & & & & & \\
\hline Chloroleucon tenuiflorum & $\mathrm{Z}$ & $\mathrm{NR}$ & d & & & & & & \\
\hline Enterolobium contortisiliquum & $\mathrm{Z}$ & $\mathrm{NR}$ & & & & & & & \\
\hline
\end{tabular}

Figure 4 Ecological characteristics and distribution of forest trees along the Uruguay River and in the first part of the Río de la Plata. The black line indicates for each species the distance from the source area to its southernmost record.
Species

Ocotea diospyrifolia

Ocotea lancifolia

Ocotea puberula

Rollinia emarginata

Guadua trinii

Merostachys claussen

Achatocarpus praecox

Ruprechtia brachysepala

Ruprechtia laxiflora

Ruprechtia salicifolia

Acanthosyris spinescens

Miconia pusilliflora

Blepharocalyx salicifolius

orectes psidiiflorus

Campomanesia guazumifolia

Campomanesia xanthocarpa

Eugenia burkartian

Eugenia repanda

Eugenia uniflora

Eugenia uruguayensis

Guapurium peruvianum

Hexachlamis edulis

Myrceugenia glaucescens

Myrcia bombycina

Myrcia laruotteana

Plinia rivularis

Psidium guajava

Psidium guineense

Psidium kennedyanum

Psidium nutans

Acosmium subelegans

Aeschynomene sensitiva

Albizia inundata

Apuleia leiocarpa

Bauhinia forficata

Bauhinia uruguayensis

Enterolobium contortisiliquum

Z NR 


\begin{tabular}{|c|c|c|c|c|c|c|c|c|c|}
\hline Species & 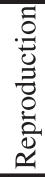 & 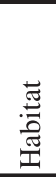 & 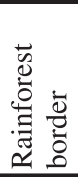 & 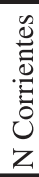 & 过 & $\begin{array}{l}\tilde{0} \\
\ddot{0} \\
0 \\
\tilde{U} \\
\text { z } \\
z\end{array}$ & 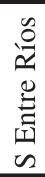 & 車 & 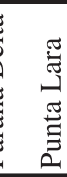 \\
\hline Gleditsia amorphoides & $\bar{Z}$ & NR & - & & & & & & \\
\hline Holocalyx balansae & $\mathrm{Z}$ & NR & 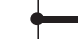 & & & & & & \\
\hline Inga semialata & $\mathrm{Z}$ & NR & - & & & & & & \\
\hline Inga verna & $\mathrm{Z}$ & $\mathrm{R}$ & & & & & & & \\
\hline Lonchocarpus leucanthus & A & NR & e & & & & & & \\
\hline Lonchocarpus muehlbergianus & A & NR & 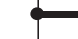 & & & & & & \\
\hline Lonchocarpus nitidus & A & NR & & & & & & & \\
\hline Machaerium aculeatum & A & $\mathrm{R}$ & $\bullet$ & & & & & & \\
\hline Machaerium minutiflorum & A & $\mathrm{R}$ & $\bullet$ & & & & & & \\
\hline Machaerium nyctitans & A & NR & e & & & & & & \\
\hline Machaerium paraguariense & A & $\mathrm{R}$ & & & & & & & \\
\hline Mimosa bimucronata & $\mathrm{Z}$ & $\mathrm{R}$ & • & & & & & & \\
\hline Myrocarpus frondosus & A & NR & & & & & & & \\
\hline Parapiptadenia rigida & A & NR & & & & & & & \\
\hline Peltophorum dubium & A & NR & & & & & & & \\
\hline Poecilanthe parviflora & $\mathrm{Z}$ & $\mathrm{R}$ & & & & & & & \\
\hline Pterogyne nitens & A & NR & & & & & & & \\
\hline Rheedia brasiliensis & $\mathrm{Z}$ & NR & & & & & & & \\
\hline Alchornea triplinervia & $\mathrm{Z}$ & NR & 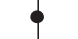 & & & & & & \\
\hline Croton urucurana & $\mathrm{Z}$ & $\mathrm{R}$ & 1 & & & & & & \\
\hline Jatropha curcas & $\mathrm{Z}$ & NR & 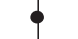 & & & & & & \\
\hline Manihot grahamii & $\mathrm{Z}$ & NR & & & & & & & \\
\hline Margaritaria nobilis & $\mathrm{Z}$ & NR & $\bullet$ & & & & & & \\
\hline Sebastiania brasiliensis & $\mathrm{Z}$ & NR & & & & & & & \\
\hline Sebastiania commersoniana & $\mathrm{Z}$ & $\mathrm{R}$ & & & & & & & \\
\hline Sebastiania schottiana & $\mathrm{Z}$ & $\mathrm{R}$ & & & & & & & \\
\hline Banara tomentosa & $\mathrm{Z}$ & NR & & & & & & & \\
\hline Casearia decandra & $\mathrm{Z}$ & NR & - & & & & & & \\
\hline Casearia sylvestris & $\mathrm{Z}$ & $\mathrm{R}$ & & & & & & & \\
\hline Xylosma venosa & $\mathrm{Z}$ & $\mathrm{R}$ & & & & & & & \\
\hline Jacaratia spinosa & $\mathrm{Z}$ & NR & & & & & & & \\
\hline Ficus adhatodaefolia & $\mathrm{Z}$ & NR & - & & & & & & \\
\hline Ficus eximia & $\mathrm{Z}$ & NR & - & & & & & & \\
\hline Ficus luschnathiana & $\mathrm{Z}$ & NR & t & & & & & & \\
\hline Maclura tinctoria & $\mathrm{Z}$ & NR & - & & & & & & \\
\hline Sorocea bonplandii & $\mathrm{Z}$ & NR & - & & & & & & \\
\hline Cecropia pachystachya & $\mathrm{Z}$ & NR & & & & & & & \\
\hline Colubrina retusa & $\mathrm{Z}$ & NR & 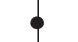 & & & & & & \\
\hline Quillaja brasiliensis & A & NR & $\bullet$ & & & & & & \\
\hline Celtis iguanaea & $\mathrm{Z}$ & $\mathrm{R}$ & & & & & & & \\
\hline Celtis pubescens & $\mathrm{Z}$ & $\mathrm{R}$ & $\bullet$ & & & & & & \\
\hline Trema micrantha & $\mathrm{Z}$ & NR & - & & & & & & \\
\hline Boehmeria caudata & $\mathrm{Z}$ & NR & 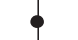 & & & & & & \\
\hline Urera baccifera & $\mathrm{Z}$ & NR & $\bullet$ & & & & & & \\
\hline Bastardiopsis densiflora & $\mathrm{Z}$ & NR & $\bullet$ & & & & & & \\
\hline Ceiba insignis & A & NR & & & & & & & \\
\hline Heliocarpus popayanensis & A & NR & 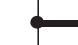 & & & & & & \\
\hline Luehea divaricata & A & NR & 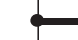 & & & & & & \\
\hline Guazuma ulmifolia & $\mathrm{Z}$ & NR & - & & & & & & \\
\hline Schinus ferox & $\mathrm{Z}$ & NR & ? & & & & & & \\
\hline Schinus lentiscifolia & $\mathrm{Z}$ & NR & ? & & & & & & \\
\hline Schinus terebinthifolius & $\mathrm{Z}$ & NR & 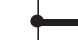 & & & & & & \\
\hline Cabralea canjerana & $\mathrm{Z}$ & NR & - & & & & & & \\
\hline Cedrela fissilis & A & NR & - & & & & & & \\
\hline Cedrela odorata & A & NR & $\bullet$ & & & & & & \\
\hline Guarea macrophylla & $\mathrm{Z}$ & NR & $\bullet$ & & & & & & \\
\hline Trichilia claussenii & $\mathrm{Z}$ & NR & $\bullet$ & & & & & & \\
\hline Trichilia elegans & $\mathrm{Z}$ & NR & $\bullet$ & & & & & & \\
\hline Trichilia pallida & $\mathrm{Z}$ & NR & $\bullet$ & & & & & & \\
\hline Balfourodendron riedelianum & A & NR & 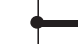 & & & & & & \\
\hline Esenbeckia grandiflora & $\mathrm{Z}$ & NR & - & & & & & & \\
\hline Fagara hyemalis & $\mathrm{Z}$ & $\mathrm{R}$ & • & & & & & & \\
\hline Fagara rhoifolia & $\mathrm{Z}$ & NR & & & & & & & \\
\hline Helietta apiculata & A & NR & & & & & & & \\
\hline
\end{tabular}

Figure 4 Continued 


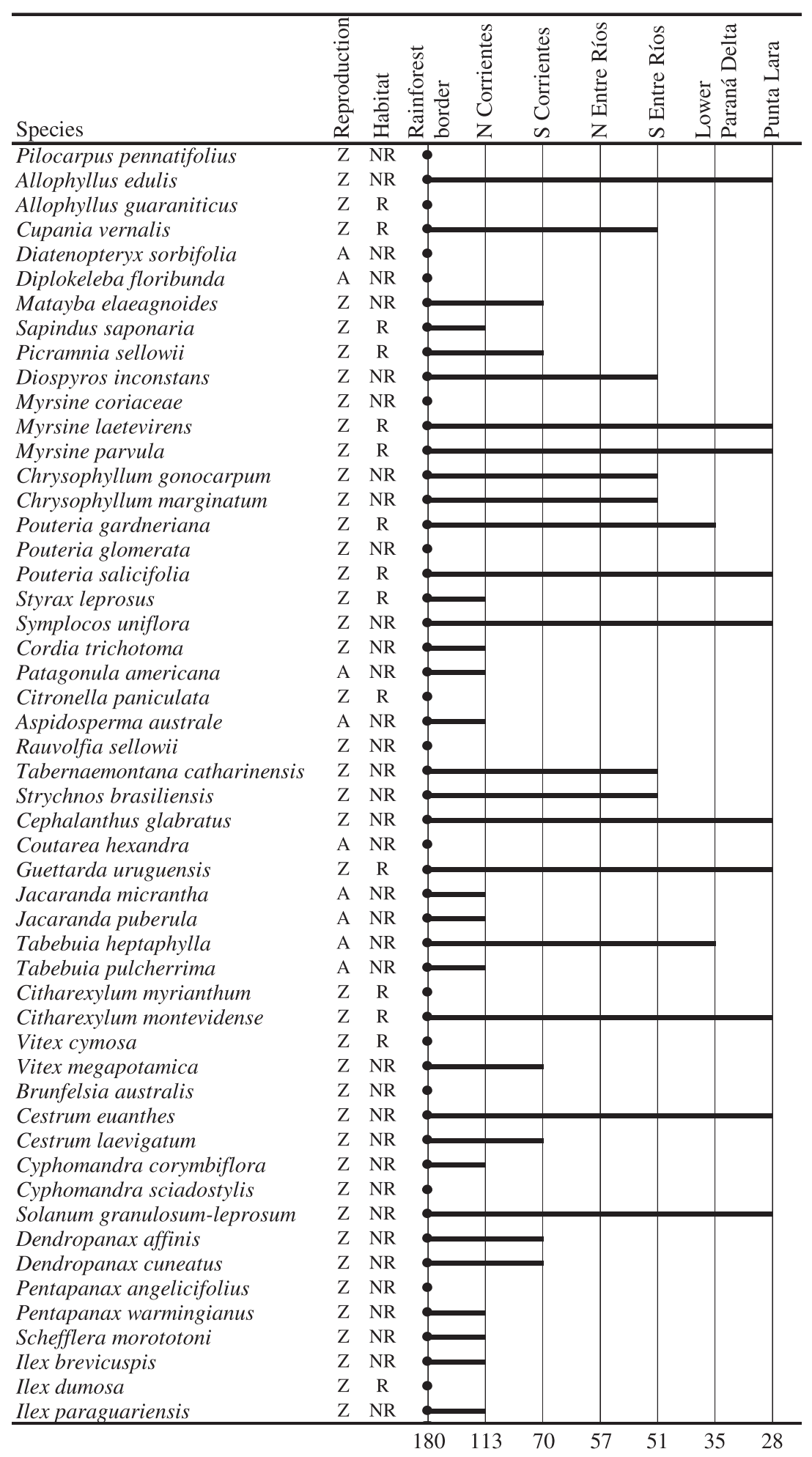

Figure 4 Continued

Species

Cupania vernalis

Diatenopteryx sorbifolia

Diplokeleba floribunda

Matayba elaeagnoides

Sapindus saponaria

Picramnia sellowi

Diospyros inconstans

Myrsine parvula

Chrysophyllum gonocarpum

Pouteria gardneriana

Patagonula americana

Citronella paniculata

Aspidosperma australe

Rauvolfia sellowi

Tabernaemontana catharinensis

Tabebuia pulcherrima

Citharexylum myrianthum

Citharexylum montevidense

Cestrum laevigatum

Cyphomandra corymbiflora

Cyphomandra sciadostylis

Solanum granulosum-leprosum

Dendropanax affinis

endropanax cuneatus

Schefflera morototoni

Ilex brevicuspis

Ilex paraguariensis ruficapillus, Phylloscartes ventralis, Turdus albicollis, Poospiza lateralis, Stephanophorus diadematus, Basileuterus culicivorus, and Basileuterus leucoblepharus in Lussich Arboretum, near Punta del Este, Uruguay).

Thirty-three bird species are shared by the two systems, but no clear pattern of the use of gallery forests is observed. Thirteen species maintain their ranges within $0-250 \mathrm{~km}$ in the two sys- tems, while the 20 remaining species differ in the distance that they advance along the rivers. For example, Basileuterus leucoblepharus and Phylloscartes ventralis, that reach the end of the gallery forest of the Uruguay River, do not go beyond $250 \mathrm{~km}$ in the gallery forests of the Cerrado region, while Philydor lichteinsteini, Automolus leucophthalmus, Sclerurus scansor, Conopophaga lineata, Mionectes rufiventris and Schiffornis virescens, which 
advance a long distance in the gallery forest of the Cerrado region, only advance a short distance (maximum $60 \mathrm{~km}$ ) in the Uruguay River. The avifauna of the Uruguay River showed a clear association pattern between size, diet, habitat use and distance reached into the gallery forest. On the contrary, no clear pattern of association was found between ecological characteristics of birds and distance reached into the Cerrado rivers (Silva, 1996).

Despite its large size, the Salto Grande dam apparently has not caused the extinction of any species because it is located at a point in the river were only a few, adaptable species reach. All the species that extended past that point are now present downstream of the dam. A proposed dam at Colonia Garabí, northeastern Corrientes, however, constitutes a great potential hazard for the forest species of the Uruguay River. As Colonia Garabí is only $60 \mathrm{~km}$ downstream from the Paranense forest border, the construction of this dam would eliminate this first $60 \mathrm{~km}$ of gallery forest and would isolate the rest for most of the species.

\section{ACKNOWLEDGEMENTS}

Very helpful comments were made on the manuscript by D. Stotz and two anonymous reviewers. M. Tablada and M. L. Nores helped us with the data. J. Heywood and J. Brasca edited the manuscript. Fieldwork was made possible by grants from Agencia Nacional de Promoción Científica y Tecnológica and Conicor.

\section{REFERENCES}

APG II (2003) Angiosperm Phylogeny Group II. Botanical Journal of the Linnean Society, 141, 399-436.

Bell, D.T. (1974) Tree stratum composition and distribution in the streamside forest. American Midland Naturalist, 92, $35-46$.

Belton, W. (1984) Birds of Rio Grande do Sul, Brazil. Part I. Bulletin of the American Museum of Natural History, 178, 369-631.

Belton, W. (1985) Birds of Rio Grande do Sul, Brazil. Part II. Bulletin of the American Museum of Natural History, 180, 1-241.

Belton, W. (1994) Aves do Rio Grande do Sul: distribução e biologia. Unisinos, São Leopoldo, Brasil.

Burkart, A., ed. (1969-79) Flora ilustrada de Entre Ríos. Colección Científica del Instituto Nacional de Tecnología Agropecuaria, 6, Buenos Aires.

Cabrera, A.L. \& Dawson, G. (1944) La selva marginal de Punta Lara en la ribera argentina del Río de la Plata. Revista del Museo de la Plata (Botánica), 22, 267-382.

Carothers, S.W., Johnson, R.R. \& Aitchison, S.W. (1974) Population structure and social organization of southwestern riparian birds. American Zoology, 14, 97-108.

Chebez, J.C. (1996) Misiones fauna. A systematic and zoogeographical catalogue of the vertebrate fauna of province of Misiones (Argentina). L.O.L.A., Buenos Aires.

Darrieu, C.A. (1986) Estudios sobre la avifauna de Corrientes. III. Nuevos registros de aves Passeriformes (Dendrocolaptidae, Furnariidae, Formicariidae, Cotingidae y Pipridae) y consideraciones sobre su distribución geográfica. Historia Natural, 6, 93-99.
Darrieu, C.A. (1987) Estudios sobre la avifauna de Corrientes. IV. Nuevos registros de aves (Passeriformes, Tyrannidae) y consideraciones sobre su distribución geográfica. Neotrópica, 33, 29-36.

Darrieu, C.A. (1990) Estudio de una colección de aves de Corrientes. I. (Dendrocolaptidae, Furnaridae). El Hornero, 13, 138-146.

Darrieu, C.A. \& Camperi, A.R. (1988) Estudios sobre la avifauna de Corrientes. V. Passeriformes poco citados (Parulidae, Thraupidae). Neotrópica, 36, 133-137.

Darrieu, C.A. \& Camperi, A.R. (1991) Estudio de una colección de aves de Corrientes. II. (Formicariidae, Cotingidae, Pipridae). Neotrópica, 37, 75-80.

Darrieu, C.A. \& Camperi, A.R. (1992) Estudio de una colección de aves de Corrientes. III. (Tyrannidae). El Hornero, 13, 219224.

Darrieu, C.A. \& Camperi, A.R. (1993a) Dos nuevos registros para la avifauna correntina: Amazilia v. versicolor (Trochilidae) y Campephilus robustus percoccineus (Picidae). Neotrópica, 39, 52.

Darrieu, C.A. \& Camperi, A.R. (1993b) Estudio de una colección de aves de Corrientes, Argentina. IV. (Phytotomidae a Parulidae). Neotrópica, 39, 83-92.

Darrieu, C.A. \& Camperi, A.R. (1994) Estudio de una colección de aves de Corrientes: Thraupidae e Icteridae. Neotrópica, 40, 49-55.

Darrieu, C.A. \& Camperi, A.R. (1996) Estudio de una colección de aves de Corrientes (Emberizidae y Fringillidae). Neotrópica, 42, 69-75.

Darrieu, C.A. \& Camperi, A.R. (1998) Estudio de una colección de aves de la provincia de Corrientes, República Argentina (Rheidae a Picidae). Physis, 55, 5-15.

Darrieu, C.A. \& Martínez, M.M. (1984) Estudios sobre la avifauna de Corrientes. I. Nuevos registros de aves (no passeres). Revista del Museo de La Plata (Zoología), 145, 257-260.

Daviña, J.R., Rodríguez, M.E., Honfi, A.I., Seijo, G.J., Insaurralde, I. \& Guillén, R. (1999) Floristic studies of the Moconá Park, Misiones, Argentina. Candollea, 54, 231-249.

Dimitri, M.J. \& (dir) (1974) La flora arbórea del Parque Nacional Iguazú. Anales de Parques Nacionales. XII. Buenos Aires.

Dimitri, M.J., Leonardis, R.F.J. \& Biloni, J.S. (1998) El nuevo libro del árbol: especies forestales de la Argentina oriental. (ed. by F. Erize). El Ateneo, Buenos Aires.

Gregory, S.V., Swanson, F.J., McKee, W.A. \& Cummins, K.W. (1991) An ecosystem perspective of riparian zones. Bioscience, 41, 540-551.

Hauman, L. (1925) La végétation de l'sle de Martín García dans le Río de la Plata. Instituto de Investigaciones Geográficas de la Facultad de Filosofía y Letras de la Universidad de Buenos Aires. Publishers no. 10, Buenos Aires.

Hueck, K. (1972) As florestas da América do Sul. Polígono, São Paulo, Brasil.

Hunziker, A.T., ed. (1994-2000). Flora fanerogámica argentina. Pugliese Siena S. R. L., Córdoba.

Hupp, C.R. (1982) Stream-grade variation and riparian-forest ecology along Passage Creek, Virginia. Bulletin of the Torrey Botanical Club, 109, 488-499. 
Hupp, C.R. (1983) Vegetation patterns on channel features in the Passage Creek gorge, Virginia. Castanea, 48, 62-72.

Johnson, M.A., Saraiva, P.M. \& Coelho, D. (1999) The role of gallery forests in the distribution of the Cerrado mammals. Revista Brasileira de Biologia, 59, 421-427.

Jozami, J.M. \& Muñoz, J.D. (1983) Árboles y arbustos indígenas de la Provincia de Entre Ríos. IPNAYS (CONICET - UNL), Santa Fe.

Kalliola, R., Salo, J., Puhakka, M. \& Rajasilta, M. (1992) New site formation and colonizing vegetation in primary succession on the western Amazon floodplains. Journal of Ecology, 79, 877901.

Kellman, M., Tackaberry, R. \& Rigg, L. (1998) Structure and function in two tropical gallery forest communities: implications for forest conservation in fragmented systems. Journal of Applied Ecology, 35, 195-206.

Knopf, F.L. (1985) Significance of riparian vegetation to breeding birds across an altitudinal cline. Riparian ecosystems and their management: reconciling conflicting uses (ed. by R.R. Johnson, C.D. Ziebell, D.R. Patten, P.F. Ffolliot and R.H. Hamre), pp. 105-111. Fort Collins, Colorado.

Mares, M.A. \& Ernest, K.A. (1995) Population and community ecology of small mammals in gallery forest in central Brazil. Journal of Mammology, 76, 750-768.

Martínez Crovetto, R. (1963) Esquema fitogeográfico de la Provincia de Misiones (República Argentina). Bonplandia, 1, $171-223$

Naiman, R.J., Décamps, H. \& Pollock, M. (1993) The role of riparian corridors in maintaining regional biodiversity. Ecological Applications, 3, 209-212.

Narosky, T. \& Di Giacomo, A.G. (1993) Las aves de la provincia de Buenos Aires: distribución y estatus. Asociación Ornitológica del Plata, Buenos Aires.

Nilsson, C. (1986) Change in riparian plant community composition along two rivers in northern Sweden. Canadian Journal of Botany, 64, 589-592.

Nilsson, C. (1992) Conservation management of riparian communities. Ecological principles of nature conservation (ed. by L. Hansson), pp. 352-372. Elsevier Applied Science, London.

Nilsson, C., Grelsson, G., Johansson, M. \& Sperens, U. (1989) Patterns of plant species richness along riverbanks. Ecology, 70, 77-84.
Nilsson, C., Jansson, R. \& Zinko, U. (1997) Long-term responses of river-margin vegetation to water-level regulation. Science, 276, 798-800.

Nilsson, C., Xiong, S., Johansson, M.E. \& Vought, L.B.M. (1999) Effects of leaf-litter accumulation on riparian plant diversity across Europe. Ecology, 80, 1770-1775.

Nores, M. (1992) Bird speciation in subtropical South America in relation to forest expansion and retraction. Auk, 109, 346357.

Redford, K.E. \& da Fonseca, G.A.B. (1986) The role of gallery forests in the zoogeography of the Cerrado's non-volant mammalian fauna. Biotropica, 18, 126-135.

Reitz, R., ed. (1965-89) Flora ilustrada catarinense. Herbário 'Barbosa Rodrigues', Itajai, Brasil.

Short, L.L. \& Horne, J.F.M. (1981) Bird observations along the Egyptian Nile. Sandgrouse, 3, 43-61.

Silva, J.M.C. (1996) Distribution of Amazonian and Atlantic birds in gallery forests of the Cerrado Region, South America. Ornitología Neotropical, 7, 1-18.

Silva, J.M.C. \& Oniki, Y. (1988) Lista preliminar da avifauna da Estação Ecológica Serra das Araras, Mato Grosso, Brasil. Boletim do Museo Paraense Emílio Goeldi (Zoologia), 4, 123143.

Stotz, D.F., Fitzpatrick, J.W., Parker, T.A. III \& Moskovits, D.K. (1996) Neotropical birds ecology and conservation. University of Chicago Press, Chicago.

Stromberg, J.C., Tiller, R. \& Richter, B. (1996) Effects of groundwater decline on riparian vegetation of semiarid regions: the San Pedro, Arizona. Ecological Applications, 6, 113-131.

Tabacchi, E., Planty-Tabacchi, A. \& Décamps, O. (1990) Continuity and discontinuity of the riparian vegetation along a fluvial corridor. Landscape Ecology, 5, 9-20.

Troncoso, N.S. \& Bacigalupo, N.M., eds. (1987) Flora ilustrada de Entre Ríos. A continuation of the work of A. Burkart. Colección Cientifica del Instituto Nacional de Tecnología Agropecuaria, 6, Buenos Aires.

Zuloaga, F.O. \& Morrone, O., eds. (1996-99) Catálogo de las plantas vasculares de la República Argentina. Missouri Botanical Garden, Missouri.

Zuloaga, F.O., Nicora, E.G., Rúgolo de Agrasar, Z.E., Morrone, O., Pensiero, J. \& Cialdella, A.M. (1994) Catálogo de la familia poaceae en la República Argentina. Missouri Botanical Garden, Missouri. 